\title{
Performing Scientific Knowledge Transfer: Anne Plumptre and the Translation of Martin Heinrich Lichtenstein's Reisen im südlichen Afrika (1811)
}

\author{
Alison E. Martin
}

In 1812, the account by the German zoologist Martin Heinrich Lichtenstein (17801857) of his South African travels, the Reisen im südlichen Afrika in den Jahren 1803, 1804, 1805 und 1806 (1811-12), appeared in English with the London publisher Henry Colburn. The Travels in Southern Africa, in the Years 1803, 1804, 1805 and 1806, translated by Anne Plumptre (1760-1818), quickly drew the attention of British critics. One of the most comprehensive accounts to emerge on the interior of Africa, Lichtenstein's travelogue drew amply on official reports, private journals and scientific papers to offer a narrative of the Cape Colony that cast itself as emphatically different than those of previous travellers, notably the British statesman Sir John Barrow's Account of Travels into the Interior of South Africa (1801-04). Yet the journalist writing in the Monthly Review, Joseph Lowe, was wary of heaping praise on the English translation of Lichtenstein's narrative: "We cannot help feeling both surprize [sic] and regret that Miss Plumptre did not take on herself the task of reducing and adapting his diffuse composition to the taste of the English public," Lowe complained (351). ${ }^{1}$ Indeed, he noted of Plumptre, she "has occasionally subjoined an [sic] useful annotation: but this serves little other purpose than to tantalize the reader with a view of the improvement which the book might have received at her hands" (351). Were she to take on another translation for Lichtenstein, Lowe concluded, "we hope that her modesty will not prevent her from lopping off his manifold exuberances" (352).

Lowe's criticisms of the apparent textual temerity of Lichtenstein's female translator are useful in enabling us to gauge early-nineteenth-century responses to women's engagement with science through translation. While the decision by some women to be involved in translation rather than authorship has often been cast as a "specifically female flight from public recognition" (Stark 37), Lowe's comments suggest that women were by no means "invisible" agents in the translation industry, nor was such invisibility deemed desirable. Indeed, his comments confirm that astute contemporary readers acknowledged the input of the translator in the translated text and considered it pivotal in shaping the character that a scientific work acquired in a different language. Lowe's observations also suggest that he condoned the presence of women translators as participants in the international transfer and circulation of scientific knowledge: his reference to Plumptre's "useful annotations" signals a readiness to accept the importance of her paratextual input in translation as a means of entering into critical dialogue with the author whose work she was putting into English. Furthermore, in upbraiding Plumptre for not having intervened more actively to abridge and "improve" Lichtenstein's account though stylistic modification, he was ascribing editorial powers to Plumptre that question traditional images of the female (scientific) translator as a submissive mediating figure. Lowe's reflections on Plumptre's involvement in the Englishing of Lichtenstein's Reisen im südlichen Afrika therefore address issues of women's visibility, scientific proficiency and intellectual self-fashioning through translation that are extremely relevant to recent 
discussions of the role of translators as social agents, whose work is shaped by the social, cultural and political context in which they work.

The concept of agency - and particularly female agency - in scientific translation has gradually acquired greater definition as scholars of translation studies have recognised the importance of understanding science writing as a creative narrative process. In his highly influential work on science and translation, Scott Montgomery has observed that "what we call 'science', today and in the past, is predominantly a reality of language - knowledge generated, shared, and used through media of written and spoken communication" (271). While Steven Shapin reminds us that the wide distribution of scientific knowledge depends very much on the success of certain cultures in creating standardised contexts for applying knowledge (7), what permits scientific knowledge to "travel" are extremely local factors that are intimately connected to the agents in the communications circuit, not least translators. Translation therefore brings into sharper focus questions as much about the universality of ideas, as about the embeddedness of scientific texts in the culture in which they were created and the motivations of those who mobilise them to present them to a potentially rather different linguistic and cultural target audience. John Milton and Paul Bandia stress that translators are often not only figures who devote great energy to the dissemination of knowledge and culture but do themselves promote cultural innovation and change, to "go against the grain, challenging commonplaces and contemporary assumptions" (1).

Early feminist translation theory was concerned precisely with the ways in which translation enabled women to communicate new insights and counter dominant (male) discourses. As Sherry Simon observed, translators "communicate, re-write, manipulate a text in order to make it available to a second language public" and in so doing "they can use language as cultural intervention, as part of an effort to alter expressions of domination, whether at the level of concepts, of syntax, or of terminology" (8). Feminist accounts of women's involvement in translation revolved for a long time around the binary opposition of writing as "original" and "masculine" versus translation as "derivative" and "female" (see: Chamberlain). More recent studies, notably Luise von Flotow's 2011 edited collection Translating Women, have shifted the emphasis away from adopting such deterministic views to highlight the flexibility and creativity adopted by female translators as they use the discursive possibilities available to them to articulate their gender in individual ways (8). Drawing on Andrew Parker and Eve Kosofsky Sedgwick's work on performativity, Flotow has argued that translation allows various "performances" of a text to take place, mobilising, transforming, and potentially subverting the original, depending on the dynamics of the contextual politics operating in the target culture (9).

Much of the research conducted into women as translators of science has focused precisely on issues of visibility. Aphra Behn, the translator of Bernard de Fontenelle's astronomical work the Entretiens sur la pluralité des mondes (1686), which appeared in English two years later as A Discovery of New Worlds (1688), clearly refused to consider translation as a marginal activity, using her translator's preface to articulate barely veiled criticism of Fontenelle's text as a piece that cast the female protagonist as intellectually inferior (see: Agorni; Martin, "No Tincture of Learning?"'). Some later female scientific translators were far less openly selfpromotional - Elizabeth Carter's translation of Francesco Algorotti's Il newtonianismo per le dame (1737) as Sir Isaac Newton's Philosophy Explain'd for the Use of Ladies (1739) did not, for example, offer her much opportunity to express 
her gendered voice (Agorni 194). Others, such as Émilie du Châtelet, demonstrated that translation was not just an exercise in linguistic transfer but also a process of critical engagement with the ideas in the source text. This was, as Agnès Whitfield has described when discussing du Châtelet's translation of Newton's Principia mathematica (1687), a process of "traduction-confirmation" [translationconfirmation] rather than "traduction-copie" [translation-copy] (109) which highlighted the intellectual challenge to which women translators of science rose, with varying degrees of success. Charles Darwin's French translator Clémence Royer, possibly presents the most radically outspoken picture of women's engagement in science through translation, Royer's prefatory disavowal of revealed religion making her translation of Darwin's work a sensational publication (Harvey 357).

While women translators such as Behn, Carter and du Châtelet now have an unassailable position in the history of science, research is increasingly turning to the more "archaeological" undertaking of identifying and analysing the work of less visible female scientific translators. In many cases, women's names did not appear on title-pages (and therefore in library catalogues) for reasons of female modesty, fear of public castigation or silencing by male agents in the publishing process. Pnina G. Abir-Am and Dorinda Outram eloquently warn of the distorting potential of gendered histories which tend to over-enthusiastically reconstruct women's roles in science (116). Jean Delisle's seminal edited collection Portraits de traductrices (2002), which contains contributions on women as translators of science, history, pedagogics and literature, is likewise not intended in a defensive activist spirit to "restore" women's contributions to the history of translation, nor does it aim to cast all of its subjects as (proto-)feminists (9). A number of subtly-argued case studies of less prominent female translators of scientific writing, particularly scientific travel literature, have begun to emerge which indicate that this is an especially productive area for further research (see: Orr; Johnston). Given that travel writing was such a bestselling genre, it is actually unsurprising that by the end of the eighteenth century, women were becoming highly prodigious translators of travelogues, working often under immense pressure of time and in fierce competition with other publishing houses. Therese Huber and Margarete Forkel were important figures in Georg Forster's "Übersetzungsfabrik" ("translation factory"), while Alexander von Humboldt's work was largely translated for the British market by women, Helen Maria Williams being responsible for the first English translation (1814-29) of his South American voyage, the Relation historique du voyage aux regions équinoxiales (1814-25) and Thomasina Ross for the second, revised edition (1852-53) some three decades later (Martin, " "These changes and accessions of knowledge").

Anne Plumptre has recently received renewed attention for her role as a translator of travel writing and as a writer who ranged confidently across a series of decidedly "unfeminine" topics that included mineralogy. As Susan Pickford, Glenn Hooper, and to a lesser degree, Isabelle Baudino, have shown, Plumptre was a woman whose own independently authored travel narratives and translations of travel writing cast her as a particularly assertive, "visible" figure in textual production. This article seeks to complement this existing scholarship on Plumptre's activities as a nonfictional translator by understanding how her rendering of Lichtenstein's work cast her specifically as a scientifically knowledgeable and linguistically adept translating woman. The performative aspect of translation that Lowe highlighted - Plumptre's extensive use of quite provocative annotation - is particularly instructive in revealing how she used paratextual devices to comment on the work she was translating, 
querying or supplementing Lichtenstein's account, and reflecting on issues of nonequivalence in translation. Her translation is therefore evidence of how linguistically distinct scientific knowledge generation was at the start of the nineteenth century, but also of its competitive potential between nations. As Plumptre was acutely aware, Lichtenstein's criticism of the authority and accuracy of preceding accounts - in particular his vitriolic treatment of the British scientist Barrow's Account of Travels into the Interior of South Africa - required diplomatic handling as she put the Reisen im südlichen Afrika into English, to ensure that she herself sidestepped direct attack and the translation did not attract a similar critical onslaught.

\section{"Moral, religious, and unexceptionable"?: Anne Plumptre as Writer and Translator}

"Miss A. Plumptre," noted the Ladies' Monthly Museum in a three-page article on her in 1817, "early discovered a propensity for the study of languages; and the encouragement of her father [...] greatly stimulated her exertions, and she acquired a competent knowledge of the French, German, Italian, and Spanish languages." Plumptre, born in Norwich as the second daughter of Robert Plumptre, prebendary of Norwich Cathedral and later president of Queen's College, Cambridge, received an uncommonly good education for a woman of her time, together with her sister Annabella, who would also go on to carve out a career for herself as a writer. Anne Plumptre's literary reputation has undergone thorough revision over the past decade or so, as knowledge of her works has expanded beyond the translations of extremely popular works by the German playwright August von Kotzebue in the 1790s for which she was hitherto best known (and which probably explains recognition in the contemporary German press of her work). ${ }^{2}$ Deborah McLeod's 1996 re-edition of Plumptre's Something New, or, Adventures of Campbell House (1801) restored this utopian novel to the accessible canon of women's late-eighteenth- and earlynineteenth-century fiction, and Katharina Rennhak's discussion of this work in combination with The History of Myself and a Friend (1817) has offered valuable insights into Plumptre's engagement with issues of gender through the first-person male narrators in each of these novels. While the Ladies' Monthly Museum rather downplayed Plumptre's "original writings," describing them as "generally read" and "moral, religious, and unexceptionable," it was more admiring of her "spirited and faithful" translations (242). Besides translating work by and on Kotzebue, she had also produced Friedrich von Mathison's Letters from Various Parts of the Continent, between the Years 1785 and 1794 (tr. 1799), Johann Carl August Musaeus' Physiognomical Travels (tr. 1800), Jean Baptiste Bertrand's Historical Relation of the Plague at Marseilles in 1720 (tr. 1805), and, after a few years' break, more travel literature in the form of François Pouqueville's Travels through the Morea, Albania, and other parts of the Ottoman Empire (tr. 1813) and Georg Heinrich von Langsdorff's Voyages and Travels to Brazil, the South Sea, Kamschatka, and Japan (tr. 1813-14).

Whether Plumptre's life was indeed as "unexceptionable" as her writings is debatable. Norwich in the 1780s and 1790s was a hotbed of provincial discontent that left Fanny Burney "truly amazed, \& half alarmed" in 1792 at how its "little Revolution Societies" fed larger committees with political ideas that were in turn transmitted to London (qtd. in Fawcett 14). Plumptre's surviving correspondence demonstrates that she associated with figures who were members of these dissident political clubs, not least the Norwich Patriots (Plumptre, Letters), who were known 
for toasting at their gatherings the parliamentary candidate Thomas Beevor who had promised to oppose "all attempts upon the liberty of the Subject and every other UNCONSTITUTIONAL measure" (qtd. in Knights 176). Correspondence dating from the 1790s shows that Plumptre was actively using the language of postRevolutionary Europe. In a letter addressed "Dear Citizen" to the political reformist George Dyer, whose writings on poverty were a call for reform that drew on Thomas Paine's Rights of Man (1791-92), she mentions the sermons of the radical orator John Thelwall, who had become intoxicated by the doctrines of 1789: listeners to his sermons in Norwich in 1796 "cannot fail I think to be improved by what they hear," she asserted (Letters). Her correspondence with Dyer is also instructive in indicating why she embarked on a career as an author and translator. Writing to Dyer about the money she had hoped to earn from a novel newly completed but turned down by Robinson - probably her first work Antoinette, which appeared with William Lane's Minerva Press in 1796 - she noted:

It is not to be sure that I am personally in want of it, for as I reduce my own private wants into as small a compass as I can I have more than sufficient already to satisfy them but I really see such misery all around me that think it a duty incumbent on me as a citizen of the world to increase [sic] as much as lies in my power by capacity of relieving it. (Letters)

As a self-professed "citizen of the world," she was not afraid to ally herself with other Norwich-born female radicals, not least Amelia Opie, with whom she enjoyed the cultural life of London in December 1800 (Brightwell 77). Plumptre's travels in 1802 to witness post-Revolutionary France first-hand were documented in her Narrative of a Three Years' Residence in France (1810), a work that scarcely endeared her with the British press, not least for her vindication of Bonaparte. Plumptre's will of 1818 , witnessed by Susannah and John Taylor, gives us an important indication of the radical dissenting circles in which she continued to move after her return from France (Plumptre, Last Will and Testament): Susannah Taylor, who allegedly danced round the tree of liberty at Norwich on the receipt of news of the taking of the Bastille, forcefully shared her husband's liberal persuasions (Martin and Goodman 50).

Norwich was not only a place of lively political debate: it was also a place of religious dissent which was key to its literary and intellectual flourishing. As David Chandler notes, the Unitarian impulse was central not only to the founding of the Norwich Public Library in 1784, but also the establishment of the Natural History Society in 1747 (Chandler 175-77). While it is now hard to prove any involvement between Plumptre and the members of the Society, it is not difficult to imagine that the interest which her work shows that she had clearly developed in science by the 1810s was stimulated by the spirit of enquiry prevailing in the city in which she lived. In a perceptive analysis of Plumptre's account of her trip to Dublin and Wicklow, Antrim and Down started in the summer of 1814, Glenn Hooper has described the Narrative of a Residence in Ireland (1817) as an "accomplished piece" that blended "unfeminine" topics as diverse as science and architecture, politics and mineralogy, while making no efforts to be self-denigrating or self-effacing (Hooper 130-32). Indeed, Hooper suggests, in the compilation of her narrative Plumptre was "drawn towards the sort of methodological procedures outlined by Lichtenstein" (130) which itself grappled with the complexities of narrative form inherent in scientific travel writing. The adoption of a quasi-scientific voice came easily to Plumptre, perhaps 
because she had already developed it in her translation of Lichtenstein's Reisen im südlichen Afrika completed a couple of years before her Irish visit. As Hooper rightly notes, she was well-versed in the use of scientific terminology and supported the assertions she made in her Irish travelogue with references from heavyweight publications such as the Journal de Physique and the Philosophical Transactions (132). She had certainly mastered a distanced, intellectually authoritative tone, as her reflections on the basalt of the Giant's Causeway demonstrate: "Where basalt does not divide itself precisely after the manner of prismatic columns [...] it often forms laminated spheroidal bodies, which varying in their diameters, constitute, by aggregation, rocks of considerable magnitude" (Plumptre, Narrative 144-45). While Plumptre's efforts as a scientific translator were, as we have seen, received favourably, the Quarterly Review was quick to sneer at her scientific pretensions as an author. The scientific sections of Plumptre's narrative were either ascribed by its reviewer to a male member of her travelling party - "the historical and geographical parts are fully equal to Lady Morgan's romance, and the scientific parts do great honour to the mineralogical footman" (338) - or the assertions she made were immediately queried as unscientific, as, for example, in the observation that " $[\mathrm{w}] \mathrm{e}$ suppose from this statement, that this scientific lady herself measured the mountain; we wish she had given us a hint or two, as to the process employed" (342).

\section{"Manly Frankness and Openness": Lichtenstein's Reisen im südlichen Afrika}

How did Plumptre come to choose Lichtenstein's travelogue for translation and publication with Colburn? This was the first piece she would translate for him, and indeed it was one of the first travel narratives that he would incorporate into his rapidly expanding range of travel literature from 1812 onwards (see: Melnyk). Plumptre would only have needed to leaf through the opening pages of Lichtenstein's Reisen im südlichen Afrika to realise that he had deliberately set out to produce an account that was not a harmless rehearsal of the facts hitherto gathered on the Cape Colony, with a few minor additions by which to make his mark on the scientific world. Nor indeed, as Lichtenstein stressed in his lengthy preface, was it full of "rare adventures and extraordinary occurrences" but rather a piece he intended to be "useful to the travelling part of the community" by focusing on the "topography, political situation, natural history, and ethnography" of South Africa and offering "what has hitherto been entirely neglected, a general history of the colony" (Lichtenstein, Travels, I: iv-v). His awareness of the corpus of writing already amassed on South Africa - previous travellers included the German astronomer Peter Kolbe, the Swedish naturalist Anders Erikson Sparrman, the French ornithologist François Le Vaillant, and the British scientist Barrow - sharpened Lichtenstein's resolve to produce as impartial an account as possible, "earnestly desirous as I was of avoiding former failures" (Lichtenstein, Travels, I: iv). Lichtenstein, a medical man, had gone out to the Cape Colony in 1804 as physician and tutor to the son of the Commissary General, Jacob Abraham de Mist, and his travels to Africa essentially launched Lichtenstein's illustrious career in science. By 1811 he had accepted a position of Professor of Zoology at the University of Berlin and in 1813 he was made director of the Zoological Museum which now forms the basis of the Berlin Museum of Natural History. Siegfried Huigen has argued that Lichtenstein's account made an extremely valuable contribution to early nineteenth-century public discourse on southern Africa not only because Lichtenstein had an intimate knowledge of the region, having crossed the interior both alone and in the company of De Mist and Hendrik Van de 
Graaf (185). He also drew on official and personal Batavian travel accounts, of which he had acquired an extensive collection during his travels. The Dutch were clearly just as interested in Lichtenstein's account as the English: a first edition of the Reizen in het zuidelyk gedeelte van Afrika, in de jaren 1803, 1804, 1805 en 1806 appeared with the Dordrecht publisher A. Blussé \& Zoon between 1813 and 1815 and a second in 1818.

Plumptre, herself a woman of forthright opinions, would not have shied away from tackling the translation of a work that openly drew swords with John Barrow's acclaimed account, weightily titled An Account of Travels into the Interior of Southern Africa. In Which is Considered, the Importance of the Cape of Good Hope to the Different European Powers, as a Naval and Military Station, as a Point of Security to our Indian Trade and Settlements during a War, and as a Territorial Acquisition and Commercial Emporium in Time of Peace: With a Statistical Sketch of the Whole Colony; Compiled from Authentic Documents. Received by critics as "among the most judicious and intelligent books of travels" (Critical Review 249) and "extremely valuable [for its] prolix statement of the argument for taking and retaining possession of the settlement" (Edinburgh Review 443), the Annual Review even suggested it was "one of the best books of travels in our own or in any language, and far, very far, the best account of the country which it describes" (22). Plumptre might well have been alert to the saleability of a provocative account casting doubt on the findings of Barrow, whose ardent imperialism would have sat ill with this provincial "citizen of the world," but there were intellectual, and perhaps also gendered, reasons as to why Lichtenstein's account drew her attention.

The index entry under "Barrow" at the end of the first volume of Lichtenstein's travelogue is instructive in understanding how in the English translation his rival was presented to a British public:

Barrow, Mr. defectiveness of his map, 36, and note - His want of liberality in the description he gives of the African colonists, $48-\mathrm{He}$ accuses the colonists wrongfully of cruelty to their oxen, 66 - His mistaken ideas concerning the Neisna lake, 198 - In an error when he considers the colonists as the aggressors in the Caffre war, 200 - His account of the Caffres, an exceedingly good one, 250 - Mistaken in his representations with regard to the colonists of Bruintjeshoogte, 360. (n. p.)

Lichtenstein's critical onslaught against Barrow's account - its "defectiveness," "mistaken ideas," wrongful accusations - stopped at almost nothing to undermine his authority as a geographer, naturalist and ethnographer. While some of the issues indexed revealed a tendency to pedantry on Lichtenstein's part - had Barrow's measurement of the eland antelope as ten-and-a-half feet long included the tail or not? (Lichtenstein, Reisen, II: 24; Travels 23-24) - others involved corrections which Lichtenstein must have thought important for future colonisers or industrialists. The Berg River was not well suited, for example, as a source of water for residents of Saldanha Bay, as Barrow had suggested, since "the Berg river itself is not at all times of the year well supplied with water" (Lichtenstein, Travels, I: 40-41) [“der Bergfluss selbst ist nicht zu jeder Jahrszeit [sic] mit Wasser versehen, wie Herr Barrow behauptet" (Lichtenstein, Reisen 65, his emphasis)].

Of greater import, as scientists tried to chart those parts of the world still not accurately mapped by Western cartographers, were Barrow's incorrect data on the 
longitude and latitude of key points. Of the location of Table Bay Lichtenstein remarked (in Plumptre's translation), "According to Mr. Barrow the mouth of the bay is in latitude $33^{\circ} 10^{\prime}$ south; -- according to my calculations it is $32^{\circ} 54$. $^{*}$ " (Lichtenstein, Travels, I: 36). He then added by way of a footnote:

*) Herr Barrow selbst gesteht im 2ten Theil seines Werks [...] die Mängel seiner Karte, wiewohl nicht mit der Offenheit und Unbefangenheit, die man verlangen könnte. Dem günstigen Zeugniß des General Vandeleur, auf den er sich beruft, muß ich das meinige entgegensetzen und behaupten, daß ich seine Karte sehr selten brauchbar gefunden habe. So liegen z. B. auch Graafreynett und die Algoabay um einen ganzen Längengrad zu weit östlich. (Lichtenstein's emphasis, Reisen 58)

*Mr. Barrow, in the second part of his Travels, acknowledges the defectiveness of his map though not with the manly frankness and openness which might be wished. Against the favourable testimony of General Vandeleur, to which he appeals, I must venture to set up my own, and observe that I seldom found it of any use: as, for example, Graaff Reynett and Algos Bay are laid down a whole degree too far eastward. (Lichtenstein, Travels, I: 36)

It is intriguing that Plumptre added the word "manly" to Lichtenstein's assertion "not with the openness and impartiality that one could demand" ["nicht mit der Offenheit und Unbefangenheit, die man verlangen könnte"] so that it read "not with the manly frankness and openness which might be wished." Perhaps she intended to imply that Barrow had not reacted in a gentlemanly fashion to the criticisms levelled at his work or that she herself would have liked to partake in such robust exchanges but was limited by female modesty. Either way, Lichtenstein's attempts to challenge the factual accuracy of Barrow's writing also undermined the British explorer's credentials as a geographer and member of the prestigious Royal Society. Lichtenstein's criticisms would also serve as ample ammunition for Barrow's rival explorer and naturalist William John Burchell. Author of the richly illustrated Travels into the Interior of South Africa (1822-24), Burchell made even shorter shrift of Barrow than Lichtenstein had done, castigating him for his pettiness, "iliberality and arrogance" and "numerous errors and misrepresentations" (qtd. in Vigne 26) concluding, "As to the miserable thing called a map, which has been prefixed to Mr. Barrow's quarto, I perfectly agree with Professor Lichtenstein, that it is so defective that it can seldom be found of any use" (Burchell, I: 577-78).

Lichtenstein took every possible occasion to demonstrate how his travels presented new (or more accurate) scientific knowledge to his readers. But he was also careful to adjust the impressions that Barrow had left of the cruelty of the Dutch colonisers and the stupidity of the "savage" indigenous peoples. Barrow, Lichtenstein asserted, "regarded every colonist as turbulent, seditious and a disturber of the public peace," based on hearsay about the Dutch by third parties rather than through the direct contact which Lichtenstein had himself enjoyed (Lichtenstein, Travels, II: 9). This certainly casts doubt on Lichtenstein's claims to impartiality, given his positive portrayal of the Dutch in whose employ and company he travelled. But where his recalibration of Barrow's account was less open to criticisms of this kind was in his portrayal of the Caffres and Hottentots. Implicitly accusing Barrow of cheap 
sensationalism Lichtenstein remarked, "of all this meritorious writer has published concerning the colony of the Cape, nothing has been read with greater avidity [...] than his accounts of the ignorance, the brutality, the filthiness, and the perseverance of the African farmers" (Lichtenstein, Travels, II: 22).

Lichtenstein's narrative therefore aimed to offer a more humane and more balanced perspective on the people whom he encountered on his travels through South Africa - an approach that would have chimed well with Plumptre and her circle of Dissenting, abolitionist friends in Norwich. Where Lichtenstein's account might also have struck a chord with Plumptre was in its recognition of the resilience of the female travellers in the party, not least Augusta de Mist, who followed her father in his migration out to the Cape. Far from presenting her as an afterthought in his account, Lichtenstein was quick to introduce to his readers this woman blessed with a "richly stored mind" (Lichtenstein, Travels, I: 11) ["vielfach gebildeter Geist" (Lichtenstein, Reisen, I: 18)] as an intriguing mix of attributes traditionally connoted as "feminine" or "masculine":

Es war überhaupt in diesem Frauenzimmer eine seltne Vereinigung weiblicher Zartheit mit einer ruhigen, fast männlichen Festigkeit, durch welche sie nicht selten den einen oder andern der übrigen Gesellschaft beschämte. (Lichtenstein, Reisen, I: 19)

There was, indeed, in this young lady a singular union of feminine softness and tenderness of heart, with a manly resolution and firmness of mind not often to be found among the rougher part of her sex; - through both she often shamed one or other of the members of our society. (Lichtenstein, Travels, I: 11)

Plumptre's translation is again revealing of her subtle manipulation of the source text to make more explicit statements about the complexity of gender, science and travel. She makes "a singular union of feminine softness and tenderness of heart" of Lichtenstein's "uncommon union of feminine tenderness" ["eine seltne Vereinigung weiblicher Zartheit"], thus highlighting the "feminine" qualities of Augusta de Mist, while at the same time turning Lichtenstein's characterisation of August as a woman with a quiet, almost masculine, resolution ["ruhigen, fast männlichen Festigkeit"] into the much less tentative "manly resolution and firmness of mind." Plumptre also adds the phrase "not often to be found among the rougher part of her sex," making of Augusta an even more unusual example of the travelling, exploring woman.

Lichtenstein presents us not only with an early example of European female travel to the Cape but one with which he asks his readers to identify:

I leave it to the readers to conceive to themselves the situation of the ladies who were of our party. Let them but revolve in their minds the occurrences of the preceding days, and then think of two young women, scarcely twenty years of age, accustomed not only to all the conveniences, but to the superfluities of life, going through a long day's journey on horseback, sleeping at night upon the sandy bank of a river, with only a dragoon's riding-cloak for a bed, and then travelling a second day almost without food and refreshment, not only half the way on foot, but climbing rugged rocks, in danger every moment of wounding their delicate hands with the stones 
and briars, and only assisted occasionally by the servants of the company. To these things must be added, the inconvenience of a woman's clothing, and the wearying manner of riding upon a woman's saddle. (Lichtenstein, Travels, I: 83)

The assumption, then, is that Lichtenstein was deliberately embracing inclusive writing, with both a male and female readership in mind. Plumptre, translating this text in her fifties, might not easily have related to the plight of the young women Lichtenstein described, but the frugality and hardship of their travels could well have had some appeal. Certainly Lichtenstein's closing assertion "Probably, few of my female readers will now be desirous of taking the same journey" (Lichtenstein, Travels, I: 83) was a challenge to which Plumptre rose as she journeyed as reader and translator through his text.

\section{"In order to exonerate myself": Plumptre's Translation of Lichtenstein's Reisen im südlichen Afrika}

Glenn Hooper has described Plumptre as "not just an interesting translator in her own right," but the "quietly unobtrusive" and "methodologically sympathetic" figure behind the English versions of Lichtenstein's work (129). There are issues, however, with Hooper's implication that she was a self-effacing and inconspicuous figure in the Travels in Southern Africa. While Plumptre did not publish a translator's preface - a paratextual device gradually being used by female translators to initiate the exchange of ideas on translation (Stark 24) - she energetically made use of what Mary Orr has termed the "footnote zone" (see: Orr), that liminal area outside the main text yet lying within the demarcations of the page, to criticise, correct and contribute to Lichtenstein's travelogue with apparent ease. The "footnote zone" operated as space in which to remark on inconsistencies or errors in terminology, to address issues of non-translatability and to tone down Lichtenstein's criticisms of Barrow. The strikingly bold translatorial voice that has been identified elsewhere in Plumptre's later translation work (Pickford 210-11) was also heard very clearly here in her translation of the Reisen im südlichen Afrika as she performed a wide variety of roles: scientific translator, terminologist, diplomat, literary commentator and specialist on the history of African exploration.

While Plumptre was not likely to move with the same freedom as male counterparts in scientific circles, she was at least aware of the terminological difficulties that translating geographical works entailed. As M. Teresa Cabré emphasises, terms are "lexical units of language that activate a specialised value when used in certain pragmatic and discursive contexts" and this value needs to be stabilised by expert communities in the field before a word acquires the status of a term (357). Plumptre was confronted with precisely these issues of terminological (in)stability and non-equivalence as she set out to deal with units of measurement. "It must here be recollected that the writer reckons by German miles, every one of which is equal to five miles English" (Lichtenstein, Travels, I: 40), she wrote in a footnote as she translated Lichtenstein's account of the point at which a shift from salt-water to fresh-water took place along the course of the River Berg. The woods in the mountains around Zwellendam near the Limpopo presented similar difficulties. Pulling at the long runner of a poisonous oleander, cynanchum obtusifolium, Lichtenstein had noted, "I was able without much trouble to draw out a young string of it, but when I had gone as far as thirteen ells,* was obliged to cut it off," to which 
Plumptre added the footnote, "*We do not know whether the Author means here the Flemish ell, which is only three-quarters of our yard, or the French ell, which is five quarters" (Lichtenstein, Travels, II: 131).

Plumptre therefore had no qualms about raising issues of translatability and reminding readers who delved into the paratextual material that the Travels in Southern Africa was a mediated text of which she was the author. Visible traces of Lichtenstein's German original were also left in the English for readers to ponder: "This place is called the Hartebeestkraal, and was one of the many stations to which the name of Ausspannplatze was given*" (Lichtenstein, Travels, I: 19, Plumptre's italicisation), noted Lichtenstein, mediated through Plumptre, as he travelled southeastwards out of Cape Town. Plumptre, struggling for an English equivalent of the German "Ausspannplatz" decided to leave it untranslated and append the following footnote:

The same reason which the German author gives in a former note for retaining the names of places, as they are called in the country, without attempting to translate them, may be urged as a reason for retaining the German term, here used ausspannplatze; since nothing of the kind being known in England, no English term could express what is meant. (Lichtenstein, Travels, I: 19)

These metatranslational moments of linguistic self-reference drew attention to the problems with which she was confronted as Lichtenstein's translator, not merely in trying to find equivalent terms but in dealing with the cultural complexity of a piece written in German about a Dutch colony, now destined for an English audience.

Plumptre's translatorial intrusions not only revolved around terminological non-equivalence and the nitty-gritty of linguistic transfer. While Plumptre may have found the controversial nature of Lichtenstein's travelogue appealing, she had clearly also realised that delicate correction of some of Lichtenstein's wilder assertions was required if his account was not to be torn apart by vicious critics, chief among them John Barrow. As Lichtenstein toured the coastal regions of South Africa to describe the Koossa (now Xhosa) tribes, he described his encounter with the Macquinas, traders who specialised in copper and iron. By way of a footnote to a passage about this tribe, Plumptre remarked:

There seems some confusion here, since the country of the Macquinas is represented by the author as to the north-west, and in the interior; yet if it were so, it could not lie between the eastern coast and Beetjuan, as it appears to do from what follows. [...] Perhaps a very unfortunate instance of misprinting has here occurred, and we ought to read "far to the northeast." Still there is a difficulty, as to its being called in the interior of the country, since from all that is said, it appears rather to be towards the eastern-coast. I have, however, given the passage exactly as it stands in the original, but have thought proper to notice it in this way in order to exonerate myself from having created the confusion. TRANSLATOR. (Lichtenstein, Travels, I: 298)

Here Plumptre not only cast herself as the critical reader, but also as the critical translator, building in what Theo Hermans has termed "ironic" translation by 
constructing a visible dislocation between translator, source text author and target text and destroying the illusion that translations are wholly mimetic and the translator little more than the author's mouthpiece (293-95). By inscribing her own subject position in her translation Plumptre could free herself from potentially being held responsible for conveying incorrect facts, while at the same time presenting herself as an intellectually enquiring woman whose role as translator was not merely that of the passive reporter. By questioning the information with which she was presented, Plumptre was therefore adopting the same practice of "translation-confirmation" that du Châtelet had used with Newton, and highlighting the intellectual reflection as much as the linguistic skills demanded by translation.

The footnotes to the Travels in Southern Africa not only demonstrate Plumptre's eye for detail. They illustrate the extremely thorough preparation work she carried out prior to translating Lichtenstein's account, which involved a weight of background reading. Plumptre demonstrated through her footnoting that she was extremely well informed on the wildlife and peoples of Southern Africa and had read other works in German (and possibly also Latin) to confirm what Lichtenstein had asserted in his account:

See Beckmann's Litteratur der alteren [sic] Reisebeschreibungen. [Compendium of Early Travel Literature] The Translator has sought in vain in Linnaeus for an account of this snake: no name corresponding to the German one is to be found; nor is the animal mentioned in Nemnich's Lexicon der Naturgeschichte [Nemnich's Lexicon of Natural History]. (Lichtenstein, Travels, I: 96)

Plumptre therefore not only showed that she was an assiduous translator, but that she understood the networks in which Lichtenstein operated and the context within which he was presenting the new inroads into science that made the Reisen im südlichen Afrika a ground-breaking account. To render his work into English meant travelling the same routes of learning and traversing the same fields of knowledge, if the translation was to be intelligent, accurate and meaningful.

While translating Lichtenstein's account therefore meant understanding how it could be situated within the corpus of work by European explorers on South Africa, Plumptre also had to draw upon her literary repertoire to save Lichtenstein from a serious mauling by British critics. Having just descended from the Sneeuberge (Afrikaans for "Snow Mountains") in the far western part of the Eastern Cape Province of South Africa, Lichtenstein related his arrival at the Towerfontein or "Enchanted Fountain," adding the following footnote, which received a metacommentary from Plumptre:

* In the same manner there are in many places about the colony mountains which bear the name of Towerberg, that is Enchanted Mountains. Mr. Barrow confuses this word with the English word Tower, and quotes thereupon, not very much to the purpose, a passage from Shakespeare, in which a hill is likened to a tower.

Above the rest,

In shape and gesture proudly eminent, Stood like a tower. $\dagger$ 
$\dagger$ It must be observed, that the German author here seems to make a mistake in the author Mr. Barrow quotes, since Mr. Barrow could hardly quote this celebrated passage of Milton as Shakespeare's. It is, besides, not a hill, but Satan that is likened to a tower. - TRANSLATOR (Lichtenstein, Travels, II: 20)

Cautiously correcting Lichtenstein, who "seems to make a mistake" as he misquotes Barrow, she emends the attribution so that it now correctly refers to Milton's Paradise Lost (lines 589-90) and seeks to restore Barrow's reputation as a man of letters in the process.

Plumptre's translation work therefore suggested considerable faith in her own abilities as she confidently offered new or corrected information to her readers to show that she had covered the same ground as her author, yet done so more carefully. Indeed, she appears to feel able to comment and criticise as if Lichtenstein's near equal. Deploying diplomacy at the right juncture was essential to her undertaking, as in this footnote pertaining to the caves at Lowenberg, near Cape Town:

The German author in citing Mr. Barrow's work always refers to a German translation of it. It must be here remarked, that either the translator of $\mathrm{Mr}$. Barrow's work, or Mr. Lichtenstein, has fallen into an error with regard to what Mr. Barrow says of the quantity of shells in this cave. He does not say that in this alone there are many thousand waggon loads of shells; he says: "Many thousand waggon loads of shells may be met with in various places along the eastern coast, in situations that are several hundred feet above the level of the sea." - TRANSLATOR. (Lichtenstein, Travels, I: 179)

Barrow, who had travelled to Cape Town just prior to Lichtenstein's exploration of the region considered himself to be one of the most important commentators on South Africa of his day. He was also one of the most acerbic of critics working for the Quarterly Review, and one with a decidedly xenophobic, perhaps Germanophobic, streak. Plumptre's comments, eager to adjust, correct and set the record straight, constituted a tactful form of manoeuvring with the aim of ensuring that Lichtenstein's account in her translation was less easily open to attack. Barrow's twenty-one-page critique was decidedly withering: "We apprehend that Doctor Lichtenstein was made 'Professor of Natural History in the University of Berlin,' in consequence of a box of insects presented to that learned body; for we find nothing in this book which indicates the slightest knowledge of the science" (Barrow 377). But it is worth pausing to reflect that without the interventions by Plumptre, who even Barrow admitted "appears to have executed her part of the work with sufficient accuracy" (394-95), the Travels in Southern Africa would have been a rather different work.

Translation, Plumptre amply demonstrated, is an interpretative undertaking that draws issues of agency, narrative identity and accountability together to generate a dialogue between source text author and translator that can have marked effects on the text that is produced in a different language. In the Travels in Southern Africa Plumptre produced a rather "discordant" narrative through her annotations, which tended to take the form of a metatranslational, self-referential commentary, as she criticised or corrected Lichtenstein's statements in her role as arbitrator and mediator between him and other scientific travellers, including Barrow. She thus constructed a 
public image of herself as a critical reader, whose combination of scientific competence and linguistic prowess cast her as a highly skilled agent in the international transmission of scientific knowledge. In line with more recent research into the performative nature of nineteenth-century science, particularly in the context of its popularisation (see: Samida), translation has much to say about how women used the interstices between the source text and its translation to position themselves as intellectually enquiring and scientifically able agents in rapidly expanding networks of knowledge. It is worth reflecting, in conclusion, that while translators can position themselves in a variety of different ways towards the text they translate, as Plumptre's annotation of Lichtenstein's narrative in English translation amply demonstrates, the text they translate also positions them. Plumptre's choice of Lichtenstein's Reisen im südlichen Afrika as a piece for translation was itself a statement of confidence in her own abilities to tackle a text that was inherently challenging on a linguistic, cultural and scientific level in ways which enabled her to make her mark within the wider scientific community. 


\section{Notes}

I particularly wish to thank the Norfolk Record Office for allowing me to access and quote from the archival material relating to Plumptre (Letters to George Dyer. 179596. MS 4262, 5B4; Last Will and Testament. 1818. MS NCC Will Register MF/RO $579 / 3$ ) in this article. I am also very glad to acknowledge the help they gave me in finding this information.

1. For the attribution of the reviewer's abbreviation 'Lo' to Joseph Lowe, see Nangle 38.

2. See the entry "Plumptre" in the 1820 edition of the Allgemeine deutsche Real-Encyclopädie für die gebildeten Stände, which could well have drawn on the 1817 article in The Ladies' Monthly Museum. 


\section{Works Cited}

Abir-Am, Pnina G. and Dorinda Outram. "Introduction." Uneasy Careers and Intimate Lives: Women in Science 1789-1979. Ed. Pnina G. Abir-Am and Dorinda Outram. New Brunswick: Rutgers UP, 1987. 1-16.

Agorni, Mirella. "The Voice of the 'Translatress': From Aphra Behn to Elizabeth Carter." The Yearbook of English Studies 28 (1998): 181-95.

Barrow, John. "Review of Travels in Southern Africa, by Heinrich Lichtenstein." The Quarterly Review 8.16 (December 1812): 374-95.

Baudino, Isabelle. "Introduction." Plumes et pinceaux: Discours de femmes sur l'art en Europe (1750-1850). Dijon: Presses du reel/INHA. Web. 30 July 2013.

Brightwell, Cecilia Lucy. Memorials of the Life of Amelia Opie, Selected and Arranged from her Letters, Diaries, and Other Manuscripts. Norwich: Fletcher and Alexander, 1854.

Burchell, William John. Travels in the Interior of Southern Africa. 2 vols. London: Longman, 1822-24.

Cabré, M. Teresa. "Terminology and Translation." Handbook of Translation Studies. Vol. 1. Ed. Yves Gambier and Luc van Doorslaer. Amsterdam: John Benjamins, 2010. 356-65.

Chandler, David. "The Athens of England': Norwich as a Literary Centre in the Late Eighteenth Century." Eighteenth-Century Studies 43.2 (2010): 171-92.

Chamberlain, Lori. "Gender and the Metaphorics of Translation." Rethinking Translation: Discourse, Subjectivity, Ideology. Ed. Lawrence Venuti. London: Routledge, 1992. 57-74.

Delisle, Jean. Portraits de traductrices. Ottawa: Presses de l'Université d'Ottawa, 2002.

Fawcett, Trevor. "Measuring the Provincial Enlightenment: The Case of Norwich." Eighteenth-Century Life 8.1 (1982): 13-27.

Flotow, Luise von. "Preface." Translating Women. Ed. Luise von Flotow. Ottawa: Ottawa UP, 2011. 1-10.

Harvey, Joy. "Darwin in a French Dress: Translating, Publishing and Supporting Darwin in Nineteenth-Century France." The Reception of Charles Darwin in Europe. Vol. 1. Ed. Eve-Marie Engels and Thomas F. Glick. London: Continuum, 2008. 354-74.

Hermans, Theo. "Positioning Translators: Voices, Views and Values in Translation." Language and Literature 23.3 (2014): 285-301.

Hooper, Glenn. "Anne Plumptre: An Independent Traveller." Gender Perspectives in Nineteenth-Century Ireland: Public and Private Spheres. Ed. Margaret Kelleher and James H. Murphy. Dublin: Irish Academic Press, 1997. 129-39.

Huigen, Siegfried. Knowledge and Colonialism: Eighteenth-century Travellers in South Africa. Leiden and Boston: Brill, 2009.

Johnston, Judith. Victorian Women and the Economies of Travel, Translation and Culture, 1830-1870. Farnham: Ashgate, 2013.

Knights, Mark. "Politics, 1660-1835." Norwich since 1550. Ed. Carole Rawcliffe and Richard Wilson. London: Palgrave Macmillan, 2004. 167-92.

Lichtenstein, Heinrich. Reisen im südlichen Afrika in den Jahren 1803, 1804, 1805 und 1806. Berlin: Salfeld, 1811-12.

---. Travels in Southern Africa, in the Years 1803, 1804, 1805, and 1806. Trans. Anne Plumptre. London: Colburn, 1812. 
Lowe, Joseph. "Review of Travels in South Africa, by Henry Lichtenstein." The Monthly Review 73 (1814): 337-52.

Martin, Alison E. “"These changes and accessions of knowledge': Translation, Scientific Travel Writing and Modernity - Alexander von Humboldt's Personal Narrative." Studies in Travel Writing 15. 1 (2011): 39-51.

---. “No Tincture of Learning?': Aphra Behn as (Re)Writer and Translator." UCL Translation in History Series, 24 October 2013. Web. 10 Dec. 2014.

Martin, Jane and Joyce Goodman. Women and Education, 1800-1980. Basingstoke: Palgrave Macmillan, 2004.

Melnyk, Veronica. "Half Fashion and Half Passion: The Life of Publisher Henry Colburn.” Diss. U of Birmingham, 2002. Web. 10 Dec. 2014.

Milton, John and Paul Bandia. "Introduction." Agents of Translation. Ed. John Milton and Paul Bandia. Amsterdam: John Benjamins, 2009. 1-18.

Montgomery, Scott L. Science in Translation: Movements of Knowledge through Cultures and Time. Chicago: U of Chicago P, 2000.

“Mrs. Anne Plumptre." The Ladies' Monthly Museum. Vol. 5 (May 1817): 241-43.

Nangle, Benjamin Christie. The Monthly Review Second Series 1790-1815: Indexes of Contributors and Articles. Oxford: Clarendon Press, 1955.

Orr, Mary. "The Stuff of Translation and Independent Female Scientific Authorship: the Case of Taxidermy..., anon. (1820) by Mrs R. Lee (1791-1856)," Journal of Literature and Science 8.1 (2015): 27-47.

Pickford, Susan. "Writing with 'Manly Vigour': Translatorial Agency in Two Early Nineteenth-Century English Translations of François Pouqueville's Voyage en Morée, à Constantinople et en Albanie (1805)." Travel Narratives in Translation, 1750-1830: Nationalism, Ideology, Gender. New York: Routledge, 2012. 197-217.

Plumptre, Anne. Letters to George Dyer, 1795-96. MS 4262, 5B4. Norfolk Record Office.

---. Last Will and Testament. 1818. MS NCC Will Register MF/RO 579/3. Norfolk Record Office.

---. Narrative of a Residence in Ireland during the Summer of 1814, and that of 1815. London: Colburn, 1817.

---. Something New: or, Adventures at Campbell-House. Ed. Deborah McLeod. Broadview: Broadview Literary Texts, 1996.

"Plumptre." Allgemeine deutsche Real-Encyclopädie für die gebildeten Stände. Vol. 7. Leipzig: Brockhaus, 1820. 633-34.

Rennhak, Katharina. "The Medium Makes the Man: Anne Plumptre's Something New and The History of Myself and My Friend." Women Constructing Men: Female Novelists and Their Male Characters, 1750-2000. Ed. Sarah S. G. Frantz and Katharina Rennhak. Lanham: Lexington Books, 2010. 45-65.

Rev. of An Account of Travels into the Interior of Southern Africa, by John Barrow. The Critical Review, or, Annals of Literature 32 (July 1801): 248-58.

Rev. of An Account of Travels into the Interior of Southern Africa, by John Barrow. The Annual Review and History of Literature 3 (January 1804): 22-33.

Rev. of An Account of Travels into the Interior of Southern Africa, by John Barrow. The Edinburgh Review 4.8 (July 1804): 443-57.

Rev. of Narrative of a Residence in Ireland during the Summer of 1814, by A. Plumptre. Quarterly Review 16 (January 1817): 337-44. 
Samida, Stefanie, ed. Inszenierte Wissenschaft: Zur Popularisierung von Wissen im 19. Jahrhundert. Bielefeld: Transcript Verlag, 2011.

Shapin, Steven. "Placing the View from Nowhere: Historical and Sociological Problems in the Location of Science." Transactions of the Institute of British Geographers 23.1 (1998): 5-12.

Shteir, Ann B. Cultivating Women, Cultivating Science. Baltimore: Johns Hopkins UP, 1996.

Simon, Sherry. Gender in Translation: Cultural Identity and the Politics of Transmission. London: Routledge, 1996.

Stark, Susanne. "Behind Inverted Commas": Translation and Anglo-German Cultural Relations in the Nineteenth Century. Clevedon: Multilingual Matters, 1999.

Vigne, Randolph. "Mapping and Promoting South Africa: Barrow and Burchell's Rivalry." Historia 58.1 (2013): 18-32.

Whitfield, Agnès. "Émilie du Châtelet, traductrice de Newton, ou la "traductionconfirmation'." Portraits de traductrices. Ed. Jean Delisle. Ottawa: Presses de l'Université d'Ottawa, 2002. 